\title{
INNOVATION IN COMPANIES AND CULTURAL ORIENTATION TO INNOVATION: A MULTILEVEL STUDY
}

\author{
LEELA L. FRANCISCHETO ${ }^{1}$ \\ (iD https://orcid.org/0000-0001-5476-1890 \\ ELAINE R. NEIVA ${ }^{1}$ \\ https://orcid.org/0000-0003-0503-3234
}

To cite this paper: Francischeto, L. L., \& Neiva, E. R. (2019). Innovation in companies and cultural orientation to innovation: A multilevel study. Revista de Administração Mackenzie, 20(3). doi:10.1590/ 1678-6971/eRAMG190135

Submission: Aug. 10, 2018. Acceptance: Nov. 26, 2018.

1 Universidade de Brasília (UnB), Brasília, DF, Brazil.

\section{(cc) BY} This is an open-access article distributed under the terms of the Creative Commons Attribution License.

This paper may be copied, distributed, displayed, transmitted or adapted if provided, in a clear and explicit way, the name of the journal, the edition, the year and the pages on which the paper was originally published, but not suggesting that RAM endorses paper reuse. This licensing term should be made explicit in cases of reuse or distribution to third parties. It is not allowed the use for commercial purposes.

Este artigo pode ser copiado, distribuído, exibido, transmitido ou adaptado desde que citados, de forma clara e explícita, o nome da revista, a edição, o ano e as páginas nas quais o artigo foi publicado originalmente, mas sem sugerir que a RAM endosse a reutilização do artigo. Esse termo de licenciamento deve ser explicitado para os casos de reutilização ou distribuição para terceiros. Não é permitido o uso para fins comerciais. 


\section{ABSTRACT}

Purpose: Test the influence of cultural orientation to innovation on the number of innovations measured in Brazilian companies.

Originality/value: The study uses an approach that has not yet been explored in the area, the multilevel analysis.

Design/methodology/approach: Five cultural orientation factors for innovation were considered: Rituals and Stories; Innovation strategies; Symbols and Heroes; Autonomy; and Standards and Communication. Innovation has been subdivided into four types: product, service, technology, and administration. The study consisted of a sample of 345 individuals in 60 organizations. The relationship between variables was analyzed using both linear regression and multilevel modeling.

Findings: The results of the regression analysis showed positive and negative relationships of all cultural factors with some kind of innovation. The multilevel analysis indicated a relationship between the two variables only in the factors Rituals and Stories and Symbols and Heroes, both at the individual level. The study indicates the existence of organizational culture characteristics that favor and inhibit innovation. In addition, the complexity of the subject and the consequent need for further studies are highlighted.

\section{KEYWORDS}

Organizational Culture. Innovation. Cultural Orientation to Innovation. Innovation Types. Multilevel Analysis. 


\section{INTRODUCTION}

The relationship between innovation and organizations is always present in strategic discussions about market positioning and competition actions. The implementation of ideas to generate procedures, practices, and better products - innovation - became an essential tool to success, performance, and organizational survival (Fagerberg, Martin, \& Anderson, 2013; Fernandes, Ferreira, \& Raposo, 2013; Steiber \& Alänge, 2013). Innovations at work are processes, outcomes, and products of attempts to develop and introduce new and improved ways of doing things, in which "creativity is the stage of generating ideas, while innovation is the subsequent implementation of these into new procedures, practices or products" (Anderson, Potocnik, \& Zhou, 2014, p. 1299).

The intention of characterizing an innovative cultural environment can also come by inspiration of organizational culture models, such as the "onion" model of Hofstede (Machado, Gomes, Trentin \& Silva, 2013). The cultural components that can be directed to the incentive to innovation would be values, rituals, heroes, norms, symbols, language, etc. These components act as drivers of human behavior in order to foster innovative actions of organizational members (Machado et al., 2013).

Many studies use cultural dimensions as independent variables that influence innovation outputs. Added to this, innovation-oriented culture (Brettel \& Cleven, 2011) and learning culture (Škerlavaj, Song \& Lee, 2010) are also considered as pertinent independent variables in affecting innovation outcomes (Tian, Deng, Zhang, \& Salmador, 2018). Innovation-oriented culture is defined as a set of organizational cultural values, norms, and artifacts that supports a company's innovativeness (Stock, Six, \& Zacharias, 2013). As a strategic direction, it emphasizes participation and autonomy of all members and shared responsibility between leaders and employees (Kenny \& Reedy, 2006; Meyer, 2014; Gomes, Machado, \& Alegre, 2015; Ali \& Park, 2016) and promotes the members of the organization to strive for innovation (Martín de Castro, Delgado-Verde, Navas-López, \& Cruz-González, 2013; Wang, Begley, Hui, \& Lee, 2012). However, it is also worth noting that there are several more research questions that require further investigation and fine-grained analysis. For example, what kinds of components are innovation-oriented cultures made of?

Considering the relevance of the theme and that it is based on Hofstede's ideas, this article deals specifically with the relationship between organizational culture and innovation by analyzing the influence of cultural orientation to innovation on the number of innovations (results) measured in Brazilian 
companies. Cultural orientation to innovation is defined by the degree to which cultural components favor organizational innovation (Stock et al., 2013). Five factors define the cultural components focused on innovation: 1. Rituals and Stories; 2. Innovation Strategies; 3. Symbols and Heroes; 4. Autonomy; and 5. Standards and Communication.

Innovation may refer to a new product or service, a new production process technology, a new structure or management system, or a new plan or program developed by the members of the organization. Among the various categories of innovation, three have drawn more attention from organizational scholars: managerial and technical; products and processes; and radical and incremental.

Characteristics of the organization and attributes of innovation can influence the organization's focus on specific types of innovation (Damanpour \& Gopalakrishnan, 2001). Different dimensions of both organizational culture and national culture have a general or overall impact on innovation (Dermici, 2013; Tian et al., 2018). In particular, studies address the distinct role played by cultural dimensions in different innovation processes, including new product development (Jassawalla \& Sashittal, 2002), service innovation (Kenny \& Reedy, 2006), administrative innovation (Kenny \& Reedy, 2006), and process innovation (Lyons et al., 2007; Kalyar \& Rafi, 2013). For the purposes of this study, innovation is subdivided into four types (product, service, technological, and administrative) and measured by the number of innovations present in the organizations in the last two years.

Culture and innovation association is a complex topic, commonly evaluated through descriptive and exploratory studies. This research aims to provide evidence of validity for a multilevel model that considers both measures at individual and at organizational levels to test the association between cultural perceptions and innovation results. Based on the controversies and difficulties in defining the appropriate level of analysis in the social sciences (Hofstede, Bond, \& Luk, 1993). The relationship between the two variables was treated in two ways in this study. Firstly, it is considered an analysis at the organizational level using linear regression. Therefore, multilevel modeling of the variables under study is carried out.

\section{THEORETICAL BACKGROUNDS}

\subsection{Culture and innovation}

Different terminologies are used to link culture and innovation: innovation culture (Dobni, 2008; Linke \& Zerfass, 2011; Sharifirad \& Ataei, 
2012; Naranjo-Valencia, Jiménez-Jiménez, \& Sanz-Valle, 2011; NaranjoValencia \& Jimènez Jimènez e Sanz-Valle, 2012; Bakovic, Lazibat, \& Sutic, 2013); culture of innovation support (Khazanchi, Lewis, \& Boyer, 2007); culture that stimulates innovation (Martins \& Terblanche, 2003); innovative culture (Hyland \& Beckett, 2005; Machado et al., 2013); culture-driven innovation (Stamm, 2009); innovation-oriented culture (Brettel and Cleven, 2011); and culture-oriented to innovation (Stock et al., 2013; Zhu \& Engels, 2014; Gobara, Rossoni, Kato, Dossa, \& Hocayen-da-Silva, 2010). Theoretical bases are diverse to cover these complex phenomena (Bruno-Faria \& Fonseca, 2014), but there is no framework that adds up propositions involving organizational culture, organizational results, and innovations.

Many facets of organizational culture have a direct impact on the innovation performance of an organization, and it depends on creativity (Demirci, 2013). Dobni (2008) points out that "in an organizational environment, innovation is often expressed through behaviors or activities that are ultimately linked to a tangible action or result" (p. 540). Beliefs, shared values, and social norms generate attitudes, subjective norms, and perceived behavioral control standards, which are determinants of intention and willingness of employees to engage in creative behavior and innovative activities that guide the way, the level, and speed of innovation (Montalvo, 2006; Nacinovic, Galetic, \& Cavlek, 2010).

A considerable group of researchers adopts organizational culture typologies associated with innovation measures in the individual, group, and organizational levels. In general, studies involve the Competing Values Framework of Cameron and Quinn (Hartnell, Ou, \& Kinicki, 2011), Schein's propositions (Hogan \& Coote, 2014; Martins \& Terblanche, 2003), and the cultural profile model (O'Reilly, Chatman, \& Caldwell, 1991). The multi-layered organizational culture model (Schein, 1990) has an influence on innovative organizational behavior and performance measures (Hogan \& Coote, 2014). Rules, artifacts, and innovative behaviors partially mediate the effects of values on a company's performance (Hogan \& Coote, 2014). Some determinants of organizational culture (strategy, structure, support mechanisms, behavior that encourages innovation and open communication) influence creativity and innovation, and values, norms, and beliefs can support or inhibit creativity and innovation (Martins \& Terblanche, 2003).

The Organizational Culture Profile (O’Reilly et al., 1991) has also been evaluated as a predictor of innovation or behaviors associated with it. Cultural consensus and organizational values in the Organizational Culture 
Profile (O'Reilley et al., 1991) are predictors of organizational innovativeness (Jaskyte and Dressler, 2005).

Perhaps the Competing Values Model (Cameron \& Quinn, 2011) is the one that presents the most consistent evidence of cultural types influencing innovation measures. The developmental culture was the strongest predictor of performance measures: product quality, product innovation, and process innovation. Rational culture shows a relationship with product quality and, along with clan cultures and hierarchical cultures, also plays an important role in predicting process quality and innovation (Dermici, 2013; Hartnell et al., 2011; Prajogo \& McDermott, 2011). Some authors have managed consistent and repeated results between types of organizational cultures that stimulate or inhibit innovations, innovation strategies, and organizational imitation, using an organizational culture instrument based on the Competing Values Framework (Naranjo-Valencia, Sanz-Valle, \& Jimenez-Jimenez, 2010; SanzValle, Naranjo-Valencia, Jimènez-Jimènez, \& Perez-Caballero, 2011; NaranjoValencia et al., 2011; Naranjo-Valencia et al., 2012). While adhocratic cultures can improve the development of new products or services, hierarchical cultures inhibit product innovation (Naranjo-Valencia et al., 2010). In addition, adhocratic cultures promote innovation strategies, and hierarchical cultures promote the imitation strategy (Naranjo-Valencia et al., 2011). The authors point out that the relationship between culture and innovation is more complex than what is shown in literature, with cycles of inhibition and incentive (Naranjo-Valencia et al., 2012).

The intention of characterizing an innovative cultural environment can also come by inspiration of organizational culture models, such as the "onion" of the Hofstede's model (Machado et al., 2013). It was conceived of the levels as being embedded one with the others like the layers of an onion, creating mutual dependency between them (Hofstede, 1998). The layers in the onion model are differentiated as follows: rituals are collective activities, technically superfluous to reaching desired ends, but within a culture are socially essential; values are the core of culture acting as broad tendencies towards the preference of certain states of affairs over others and are acquired early in our lives; heroes are persons (alive or dead, real or imaginary) who possess characteristics that are highly prized in a culture and serve as models for behavior; symbols are words, gestures, or objects that carry a particular meaning but are only recognized as such by those who share a culture; norms are unwritten guidelines in a society that govern the actions and behaviors of its members. These components act as drivers of human behavior in order to foster innovative actions of organizational members (Machado et al., 2013). 
The components represent the ideas that people have about how things "ought to be". They strongly influence the behavior of people. In an organization, formalized types of behavior that are sanctioned by the social collective are called "practices". Although they are visible, they carry intangible cultural meanings that extend across all the three outer layers. Moreover, culture is composed of implicit and explicit patterns of social behavior through the acquisition and transmission of its symbols (Hyland \& Beckett, 2005; Machado et al., 2013). In addition, other reflections of culture occur in communication, manners, dress codes, social rules, and role models. Hence, it could be said that culture is historically derived and composed of selected ideas and their attached values. It results from the accumulated experiences of action, and it conditions future actions (Hyland \& Beckett, 2005; Machado et al., 2013).

Several other dimensions are also listed as components of a culture for innovation: support innovation, risk propensity, and tendency for generating ideas are also attached to defined types of innovation - product, process, management, market, and ad hoc (Gobara et al., 2010); autonomy, proactivity, and risk propensity (radical innovation culture) also influence product innovations (Bakovic et al., 2013; Tellis, Prabhu, \& Chandy, 2009). Five dimensions of organizational culture (goal orientation, orientation to innovation, structured leadership, support leadership, and collaboration among members) were significantly related to implementation innovations (Zhu \& Engels, 2014). Innovation-oriented culture (Brettel \& Cleven, 2011) is also considered as a pertinent independent variable in affecting innovation outcomes (Tian et al., 2018). Innovation-oriented culture is defined as a set of organizational cultural values, norms, and artifacts that supports a company's innovativeness (Stock et al., 2013). As a strategic direction, it emphasizes participation and autonomy of all members and shared responsibility between leaders and employees (Kenny \& Reedy, 2006; Meyer, 2014; Gomes et al., 2015; Ali \& Park, 2016) and promotes the members of the organization to strive for innovation (Martín-de Castro et al., 2013; Wang et al., 2012).

Authors reiterate the level of analysis, arguing that organizational culture is an integral aggregate variable in which a referent is a group of individuals, but it cannot be reduced to a list of the individuals' properties (Jaskyte \& Dressler, 2005). Composed of individual perceptions, culture is a complex shared phenomenon and for this reason, it must be analyzed in a multilevel perspective (Anderson et al., 2014; Büschgens, Bausch, \& Balkin, 2013; Fagerberg et al., 2013). 


\subsection{Multilevel analysis}

The social sciences usually encounter a dilemma: the definition of the level of analysis. The subjects under analysis are usually individuals' behaviors or properties of social systems formed by individuals. Thus, data are collected from individuals (e.g., questionnaires). The problem becomes evident, however, only when the conclusions regarding one level of analysis are available at another level of analysis (Hofstede et al., 1993).

The nature of research in the social sciences is the first point Hox (2002) raises when referring to multilevel research. The multilevel survey is therefore characterized by a hierarchical data structure and by a stepwise sample, coming from a hierarchical population (Hox, 2002). Thus, variables can be defined at any level of analysis, and they can migrate from one level to another by aggregating (from a lower to a higher level) or disaggregating (from a higher level to a lower level) the data (Hox, 2002).

The multilevel analysis arises by observing that, in contextual modeling, the individual and context are distinct sources of variability and should, therefore, be modeled as random influences (Snijders \& Bosker, 2012). The relationships established are of the macro-micro or micro-macro types. The first is the most common in the literature and refers to a variable at the level of the group interfering in the individual. The second aspect is the opposite - that is, a micro level variable affecting a macro level variable (Snijders \& Bosker, 2012).

In this study, aggregate measures are reflexive constructs - that is, the referent is the group as a whole. In this way, the group level construct is the cause of individual-level indicators. In this case, it is considered important to analyze the variation within each group (ICC), which represents the lack of agreement of the individuals in relation to the group level construct, to estimate the sample error at the group level (Lüdtke, Marsh, Robitzsch, Trautwein, Asparouhov \& Muthén, 2008).

\subsection{Multilevel model}

In this study two levels of analysis of the model are established: the first level (L1) is formed by the members of the organizations studied, and the second level (L2) is formed by the organizations surveyed. The prediction model considers the organizational culture variable at the individual level as well as at the group level, both of which are explanatory variables, and innovation as the response variable at the highest level (Figure 2.3.1). 
(Figure 2.3.1)

SCHEMATIC REPRESENTATION OF THE PROPOSED MULTILEVEL THEORETICAL MODEL FOR LEVELS 1 AND 2

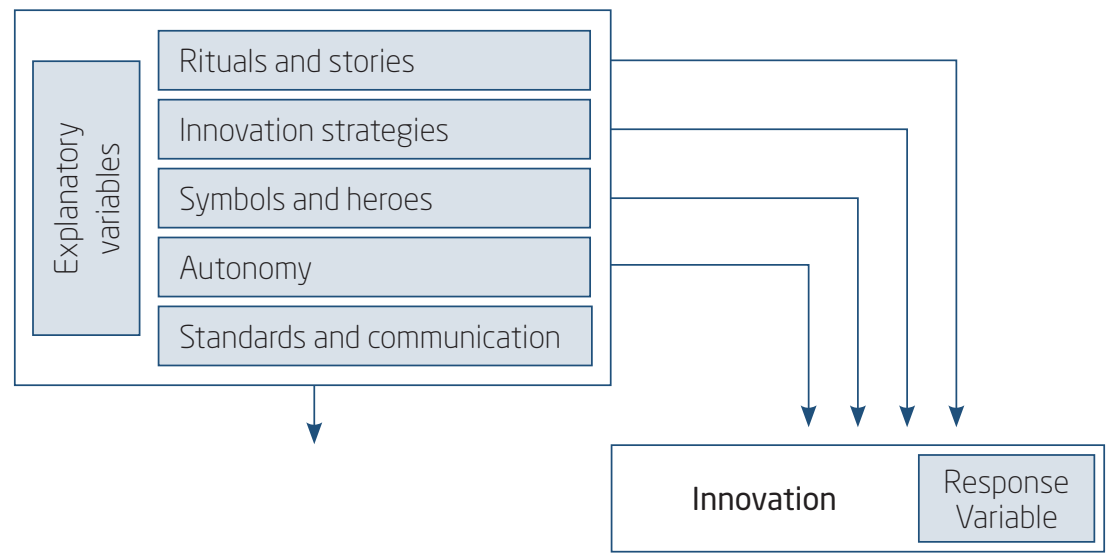

Level 2 - Firms

Level 1 - Organization members

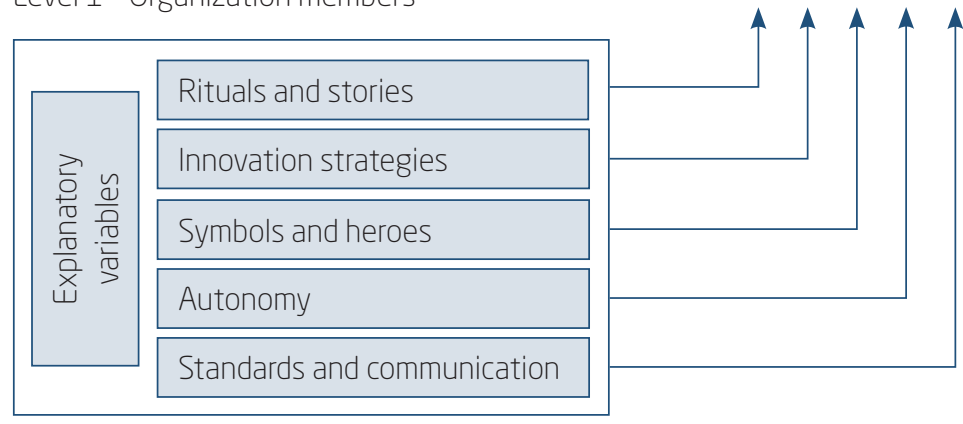

Source: Elaborated by the authors.

Based on the proposed theoretical model, it is expected that the explanatory variables of organizational culture, level 1 and level 2, predict significant variance in the innovation response variable (Figure 2.3.1).

The cultural orientation to innovation is evaluated by the degree to which cultural components favor innovation in the organization (Stock et al., 2013; Chen, Farh, Campbell-Bush, Wu, \& Wu, 2013), these being Rituals and Stories; Innovation Strategies; Symbols and Heroes; Autonomy; and Standards and Communication. Innovation is the implementation of ideas toward better procedures, practices, and products (Anderson et al., 2014), measured by the number of product, service, technological, and administrative innovations. 
As listed above, based on Lüdtke et al. (2008), it is possible to predict a response variable at the group level by the latent covariant multilevel model (MLC), which is used in this study. The hypotheses are then presented considering the two levels evaluated.

Organizational culture is defined as a feature of the organization as a whole, not of the individuals who are part of it. After all, culture is perpetuated even if there is employee turnover. Access to cultural characteristics can occur through individual perceptions though (Hofstede et al., 1993). Although organizational culture is considered a group variable, Hofstede, Bond, and Luck (1993) also perform an analysis of the individual perceptions of the organizational culture - that is, at the individual level - which form the basis for the hypotheses at level 1 . However, empirical literature is not clear on the types of culture that enhance or inhibit innovation (Büschgens et al., 2013; Chang \& Lee, 2007; Lau \& Ngo, 2004; Lin, Chuang, Chang, \& Yeh, 2012; Miron, Erez, \& Naveh, 2004; Naranjo-Valencia, Jiménez-Jiménez \& Sanz-Valle, 2016). Drawing from the definition of organizational culture, innovation culture can be thought of as organizational widely shared basic values and norms that support innovation and perceptible innovationoriented practices - that is, artifacts and behaviors. Scholars and practitioners have attempted to research on which values, norms, and practices support an innovation culture.

Rituals and stories are acknowledged in literature as trainers of organizational culture (Pettigrew, 1979; Schein, 2010). Culture is seen as the element that provides the interpretation of organizational history and guides behaviors (Pettigrew, 1979; Schein, 2010) through daily practices that are anchored in observable elements such as rituals (Hofstede, 1998). The presence of stories through myths (narratives) is also found in the literature, as an important creator and cultural precursor, and rituals/rites are interpreted as reinforcers of group mythology (Hofstede et al., 1993; Jarnagin \& Slocum Jr., 2007). Rituals and stories are powerful means of building relationships among people, and these relationships can foster important behaviors for innovation outcomes. Rituals and stories are technically superficial collective activities, but are socially essential within a culture and involve facts and verbal descriptions of facts that contributed or should be avoided on innovation or on process of innovation in product, processes, and/or management (Machado \& Vasconcellos, 2007; Machado et al., 2013).

- H1a: the rituals and stories the members of the organization perceive are positively associated with innovation in the organization. 
- H1b: rituals and stories at the organization level are positively associated with organizational innovation.

The strategies of great organizational impact require cultural changes to generate successful results (Cameron \& Quinn, 2011) and are therefore considered and investigated as determinants of innovation (Martins \& Terblanche, 2003). Tidd, Bessant, and Pavitt (2005) developed a diamond model of managing innovation that considers whether innovation is a strategic focus of the organization (Cameron \& Quinn, 2011). This cultural influence looks at how the internal procedures are designed to support new products or services and that everyone is involved in the innovation process. The company must be clear about what drives it to innovate. The pursuit of new ideas of innovation requires direction. The company must establish clearly where it wants to innovate; what themes, problems or opportunities to prioritize; and what activities will foster the desirable innovation (Martins \& Terblanche, 2003; Tian et al., 2018).

- H2a: the innovation strategies the members of the organization perceive are positively associated with the innovation in the organization.

- H2b: innovation strategies at the organizational level are positively associated with organizational innovation.

The core of culture consists of daily practices, which are anchored in observable elements such as these heroes, symbols, and rituals (Hofstede, 1998). Based on anthropological theories, Pettigrew (1979) was one of the pioneers to use the term organizational culture. He defines it by considering the following elements: symbols, languages, ideologies, beliefs, rituals, and myths, highlighting symbols as the most inclusive category and as a cultural frame of reference. Heroes are a special kind of symbol, with characteristics highly valued, who serve as a model of behavior (Hofstede, 1998) and are important representatives of the founders' and leaders' category (Schein, 2010; Cameron \& Quinn, 2011; Yin, Lu, Yang, \& Jing, 2014). Those are creators (Yin et al., 2014), managers, and perpetrators of organizational culture (Cameron \& Quinn, 2011; Schein 1990; Pettigrew 1979). Symbols and heroes determine the way the organization is perceived and provide knowledge and information about the world. Through staying together, people gain knowledge about what is good and what is bad and what the organization expects from them. These cultural aspects develop ready-made patterns of behavior and action in specific situations by perceiving organizational reality and the environment as relatively comprehensible (Yin et al., 2014). 
- H3a: the symbols and heroes the members of the organization perceive are positively associated with the innovation in the organization.

- H3b: symbols and heroes at the organizational level are positively associated with organizational innovation.

Organizations with innovative cultures are the most sought after by people who need autonomy to work (O’Reilly et al., 1991), and this autonomy strengthens the organization's innovation (Lin et al., 2012). Autonomy in the work environment is considered in the literature as a propelling element of creativity and innovation (Nacinovic et al., 2010). Mumford (2000) argues that innovation relies on the conception of novel and inventive ideas and is achieved by combining creativity and implementation of such ideas. An organization requires creative people to develop the concepts, as well as people to select, assess, and execute the ideas (Jamrog, Vickers, \& Bear, 2006; McLean, 2005). An innovative firm should, therefore, allow employees' freedom and time to come up with new and creative ideas and experiment on those ideas. Freedom is evidenced in empowerment, autonomy, and participation in decision making (Isaksen \& Ekvall, 2010; Martins \& Martins, 2002). An environment of autonomy will increase employees' intrinsic motivation. This subsequently promotes creativity, which is core to promoting innovation (McLean, 2005). Regarding risk-taking, successful innovation is rarely achieved on the first try. Breakthrough innovation is usually a culmination of several trials, experiments, and iterations (Martins \& Martins, 2002).

- H4a: the autonomy the members of the organization perceive is positively associated with the innovation in the organization.

- H4b: autonomy at the organizational level is positively associated with organizational innovation.

Standards are elements constructed in a distinct way in each organizational culture and guides of behaviors and attitudes in the work environment (Schneider, Ehrhart, \& Macey, 2013; Nacinovic et al., 2010). All the elements constituting the organizational culture are communicated to the group (Schneider et al., 2013) explicitly or implicitly, with a view to their incorporation or sharing in the group. In this way, behavior encouraged by standards can support or inhibit innovation (Martins \& Terblanche, 2003; Pratoom \& Savatsomboon, 2012; Hogan \& Coote, 2014). Innovation is a collective good in that its generation is the result of a process that combines pieces of information, knowledge, and norms that are owned by a variety of parties and cannot be traded as such. The conditions and features of communication 
processes explain the clustering of innovations in organizational spaces (Pratoom \& Savatsomboon, 2012; Hogan \& Coote, 2014). Communication cannot be defined as a means to transfer and effectuate knowledge and innovation from the top down, but it is also necessary to look at its potential and characteristics in the process of constructing innovations as an outcome of ongoing social interaction (Pratoom \& Savatsomboon, 2012; Hogan \& Coote, 2014; Schneider et al., 2013).

- H5a: the standards and communication the members of the organization perceive are positively associated with the innovation in the organization.

- H5b: standards and communication at the organizational level are positively associated with innovation in the organization.

Most empirical studies use instruments applied at the individual level to access the organizational culture variable and aggregate the data to be evaluated at the organizational level (Jaskyte \& Dressler, 2005; NaranjoValencia et al., 2011; Sanz-Valle et al., 2011; Martins \& Terblanche, 2003; Hogan \& Coote, 2014; Dobni, 2008; Zhu \& Engels, 2014; Bakovic et al., 2013). However, considering the literature on the reliability of aggregate measures and their possible bias in the context effect, in addition to the traditional regression analysis, an analysis is proposed that considers the inclusion of variables at different levels.

\section{METHOD}

\subsection{Participants}

The collected sample consisted of 345 respondents, distributed in 60 organizations. Among those surveyed, $52.3 \%$ were women, the mean age was 30.23 years $(S D=9.08)$, and the mean duration of their respective work contracts was 30.17 months $(S D=38.47)$. All the organizations were located in the Federal District (city center), with $36 \%$ in the Plano Piloto and $29.6 \%$ in Taguatinga, with an average number of 18.94 employees per organization ( $\mathrm{SD}=16.57$ ) and an average time of existence of 11.44 years $(\mathrm{SD}=9.447)$. Plano Piloto and Taguatinga are areas in the Federal District, Brasília, Brazil. The companies surveyed were active in diversified areas, such as restaurants, construction shops, drugstores, pet shops, consultancies, and photography studios.

For the regression analysis, the univariate and multivariate extreme cases were extracted, due to their effect in the model. These cases have been 
detected by Mahalanobis distance, and maintaining them in the model reduced the regression coefficients, so they were extracted. The sample was therefore reduced to 317 respondents and 54 organizations. The organizations had an average of 19.9 employees (SD $=16,847)$, a mean time of 11.62 years of existence $(S D=9,681)$, being $33.1 \%$ located in Plano Piloto and $29.7 \%$ in Taguatinga. The sample of employees had a mean age of 30.25 years $(\mathrm{SD}=9.125)$ and worked in their respective company for an average time of 29.84 months ( $\mathrm{SD}=39.242$ ), and $51.9 \%$ were women. About $32 \%$ of participants held senior positions (insert) in people leading roles while the others were employees of various non-managerial positions in the organizations involved in the study.

The power of the sample, calculated using $\mathrm{G}^{*}$ Power software, was 0.945 for the total of 54 organizations evaluated in the linear regression.

\subsection{Data collection}

In order to obtain access to companies in the Federal District, the Commercial and Industrial Association of Taguatinga (ACIT) and SEBRAE were contacted for listings of companies interested in participating. The contact resulted in a total of 65 organizations, five of which were not willing to participate. The data collection involves information from at least five respondents in each organization.

The two instruments were applied personally to each organization. The Cultural Orientation to Innovation Scale was applied to at least $30 \%$ of the members of the organization, and the Innovation Instrument was applied to a partner or manager. The first instrument, delivered separately to each subject, contained a brief study objective and necessary instructions for response and was completed individually. The second instrument was applied orally, beginning with a brief description of the study objectives and the instructions for a response. Answers were written down and recorded, except for participants who did not authorize recording. The application took place during 3 months, ranging from the reception of the lists of companies to the scheduling of visits and collection of the data.

\subsection{Measures}

The measure of the organizational culture used took the form of a survey applied to the members of the organization. Thus, the measure was obtained at the individual level, but the organizational culture was measured both at the individual level and at the group level, through the aggregation of the 
variable. The measure of innovation was collected from partners or managers and quantified as the number of innovations occurred in each organization, being, therefore, a group-level variable. The following instruments were used:

- Cultural Orientation for Innovation Scale: The full version of the Cultural Orientation for Innovation Scale (COIS) was used, consisting of 54 items. Respondents could choose values on a seven-point scale $(1=$ Strongly Disagree to $7=$ Strongly Agree) (Francischeto, 2016). This is a multi-item scale in which the variables were measured in a reflexive and formative way. The scale was submitted to an exploratory factorial analysis with good indexes of validity and reliability. The factory loads were above 0.50 , and the variance explained by the instrument was up to $52 \%$.

The items referred to cultural characteristics of the organization that could lead to the stimulation or inhibition of innovation (e.g., "In the company, stories are told about their successful innovations"). The EOCI is composed of five factors: Rituals and Stories (nine items; $\alpha=0.907$ ); Innovation Strategies (eight items; $\alpha=0.859$ ); Symbols and Heroes (six items; $\alpha=0.853$ ); Autonomy (eight items; $\alpha=0.803$ ); and Standards and Communication (six items; $\alpha=0.861$ ) (Francischeto, 2016). These measures were used on two levels: individual and organizational. The difference between the measures of the two levels (individual and organizational) lies in the fact that variables at the organizational level are aggregate measures of respondents' responses. Aggregate means of variables by the organization were calculated for each factor of cultural orientation for innovation.

- Innovation Measure: The innovation was evaluated through an interview. The variable was subdivided into four types: Product Innovation; Service Innovation; Technological Process Innovation; and Innovation of Administrative Processes. For each type of innovation, its respective concept was presented based on the literature, and three questions were asked, considering the past two years of the organization: 1 . Whether the type of innovation reported occurred; 2 . The number of innovations of that type; and 3. A brief description of the innovations that occurred.

The types of innovation were defined as follows:

1. Product innovation: products or services introduced to reach an external user or market need (Ettlie \& Reza, 1992; Knight, 1967; Utterback \& Abernathy, 1975 apud Damanpour \& Gopalakrishnan, 2001). 
2. Service innovation: introduction of new services to existing customers or new customers and the provision of existing services to new customers (Damanpour, Walker, \& Avellaneda, 2009).

3. Innovations in technological processes: new elements introduced into a production or service operation system to produce a product or service (Ettlie and Reza, 1992; Knight, 1967; Utterback and Abernathy, 1975 apud Damanpour \& Gopalakrishnan, 2001).

4. Organizational process innovations: new approaches and practices to motivate and reward members of the organization, invent strategies and task and unit structures, and modify the organization's management process (Damanpour et al., 2009).

Three judges who were experts in innovation collected the responses from each organization. They inquired whether the reports were indeed innovations or not and classified the innovations according to the defined types. The three analyses were compiled, generating the quantities of innovations in the companies by type of innovation in addition to the total number of innovations in each organization.

\subsection{Data analysis}

In order to reduce the number of variables from the Cultural Orientation for Innovation Scale to a smaller set with maximum variability and reliability (Pasquali, 2012), exploratory factor analysis and the determination of the representative factors were first performed. Then, factor scores were calculated, corresponding to the mean of the variables of each factor. First, linear regression was performed with the explanatory variables aggregated. Linear regression was used to test the model at the group level, and hypotheses H1b, H2b, H3b, H4b, and H5b were evaluated. All multicollinearity tests showed the variance inflation factor (VIF) below 2.5 and tolerance values greater than 0.1 , and these results allowed the analyses. Then, the analyses of the multilevel model were performed, testing the influence of the individual explanatory variable on the group response variable, corresponding to hypotheses $\mathrm{H} 1 \mathrm{a}, \mathrm{H} 2 \mathrm{a}, \mathrm{H} 3 \mathrm{a}, \mathrm{H} 4 \mathrm{a}$, and $\mathrm{H} 5 \mathrm{a}$. Then, the influence of the group explanatory variable on the group response variable was tested, corresponding to the hypotheses $\mathrm{H} 1 \mathrm{~b}, \mathrm{H} 2 \mathrm{~b}, \mathrm{H} 3 \mathrm{~b}, \mathrm{H} 4 \mathrm{~b}$, and $\mathrm{H} 5 \mathrm{~b}$. For the multilevel analyses, the six steps suggested in the literature were followed (Snijders \& Bosker, 2002). The first step was to calculate the empty model without explanatory variables, which presented the initial parameters of ICC and deviance. The second step was the addition of the 
individual-level variables with a fixed parameter - that is, considering that they do not differentiate between groups, these being Rituals and Stories, Innovation Strategies, Symbols and Heroes, Autonomy, and Standards and Communication. The third step was the addition of group-level variables.

This study adopts the multilevel latent covariate model (MLC) of Lüdtke et al. (2008), which evaluates micro-macro situations and proposes to control the lack of reliability of the group mean by introducing an unobserved latent construct.

\section{RESULTS}

\subsection{Comparative results}

It can be assumed that there are differences among organizations that permit an analysis at the organizational level. In order to confirm the intergroup differences (organizations' differences) and the cohesion within the groups, however, one-way ANOVAs were calculated for each factor, as well as the Intraclass Correlation Indices (ICC) in Figure 4.1.1. ANOVA results show differences between all groups (organizations) for cultural orientation factors: Rituals and Stories ( $\mathrm{f}=3,9543 ; \mathrm{p}=0,000)$; Innovation Strategies $(\mathrm{f}=$ $3,311 ; \mathrm{p}=0,000)$; Symbols and Heroes ( $\mathrm{f}=3,812 ; \mathrm{p}=0,000)$; Autonomy $(\mathrm{f}=5,747 ; \mathrm{p}=0,000)$; and Standards and Communication $(\mathrm{f}=2,769 ; \mathrm{p}=$ $0,000)$. The one-way ANOVA result was significant in all factors $(\mathrm{p}<0.01)$, reinforcing the existence of variability among the organizations studied.

(Figure 4.1.1)

INTRACLASS CORRELATION INDICES (ICC)

\begin{tabular}{lccc}
\hline \multicolumn{1}{c}{ Factor } & ICC & Error variance & Group variance \\
\hline Rituals and stories & 0.367 & 1.877 & 1.087 \\
\hline Innovation strategies & 0.275 & 0.925 & 0.351 \\
\hline Symbols and heroes & 0.321 & 1.394 & 0.660 \\
\hline Autonomy & 0.440 & 0.802 & 0.629 \\
\hline Standards and Communication & 0.271 & 1.627 & 0.606 \\
\hline
\end{tabular}

Source: Elaborated by the authors.

ICC values range from 0 to 1 , with values close to 0 representing homogeneity among the samples and nullifying the company's differentiated perception of the factor. The results, therefore, confirmed the presence of 
sharing of the phenomenon among the members of each company. In order to verify the reliability of means, the Spearman-Brown formula was used, as suggested by James (1982). The ICC values (2) were calculated for each factor: Rituals and Histories (ICC2 $=0.994)$; Innovation Strategies $($ ICC2 = 0.990); Symbols and Heroes (ICC2 = 0.993); Autonomy (ICC2 = 0.995); Standards and Communication (ICC2 $=0.991)$. The results of ICC and ICC (2) demonstrated, respectively, differentiation among organizations, following the average criterion of James (1982) and reliability and stability of the means.

In order to evaluate the homogeneity of the responses, the internal agreement coefficient (r_wg) was calculated, proposed by James, Demaree, and Wolf $(1984,1993)$. The literature shows values of $r_{-}$wg higher than 0.70 as indicative of the appropriateness of aggregating individual responses at the group level, although values up to 0.50 can be accepted as moderate (James et al., 1984). All the internal agreement coefficients of the companies regarding the factors of the instrument were higher than 0.50 , which demonstrates the level of responses homogeneity. These data allow aggregating collected data at the individual level to the level of groups, in this case, organizations.

\subsection{Results of linear regression}

Correlations between the variables are presented in Figures 4.2.1 and 4.2.2. There are correlations between all factors of cultural orientation and innovation measures. In addition, these correlations are more robust among organizational-level variables.

\section{(Figure 4.2.1)}

CORRELATIONS OF VARIABLES AT INDIVIDUAL LEVEL

\begin{tabular}{|c|c|c|c|c|c|}
\hline Variables & $\begin{array}{l}\text { General innovation } \\
\text { index }\end{array}$ & INOPRO & INOSERV & INOTEC & INOADM \\
\hline Rituals and stories & $0.207^{\star \star}$ & $0.134^{*}$ & $0.260^{\star *}$ & $0.217^{\star \star}$ & $0.190^{\star *}$ \\
\hline Innovation strategy & $0.175^{\star \star}$ & $0.130^{\star}$ & 0.102 & $0.202^{\star \star}$ & $0.120 *$ \\
\hline Symbols and heroes & $0.156^{\star \star}$ & 0.106 & $0.151^{\star \star}$ & $0.161^{\star \star}$ & $0.137^{\star}$ \\
\hline Autonomy & 0.084 & 0.048 & $0.182^{\star \star}$ & $0.120^{*}$ & 0.056 \\
\hline Standarts and communication & $0.175^{\star \star}$ & $0.123^{\star}$ & $0.204^{\star \star}$ & $0.177^{\star \star}$ & $0.115^{\star}$ \\
\hline N & 317 & 317 & 317 & 317 & 317 \\
\hline
\end{tabular}

* Correlation is significant at the 0.05 level (2-tailed).

** Correlation is significant at the 0.01 level (2-tailed). 
(Figure 4.2.2)

CORRELATIONS OF VARIABLES AT ORGANIZATION LEVEL

\begin{tabular}{lccccc}
\hline Variables & $\begin{array}{c}\text { Rituals and } \\
\text { stories - } \\
\text { organizational } \\
\text { level }\end{array}$ & $\begin{array}{c}\text { Innovation } \\
\text { strategy - } \\
\text { organizational } \\
\text { level }\end{array}$ & $\begin{array}{c}\text { Symbols and } \\
\text { heroes - } \\
\text { organizational } \\
\text { level }\end{array}$ & $\begin{array}{c}\text { Standarts and } \\
\text { communication - } \\
\text { organizational } \\
\text { level }\end{array}$ & $\begin{array}{c}\text { Autonomy - } \\
\text { organizational } \\
\text { level }\end{array}$ \\
\hline $\begin{array}{l}\text { General innovation } \\
\text { index }\end{array}$ & $0.328^{*}$ & $0.324^{*}$ & $0.308^{*}$ & 0.213 & $0.337^{*}$ \\
\hline INOPRO & 0.250 & 0.254 & 0.243 & 0.153 & $0.288^{*}$ \\
\hline INOSERV & $0.352^{* *}$ & 0.245 & $0.281^{*}$ & $0.335^{*}$ & 0.264 \\
\hline INOTEC & 0.178 & $0.273^{*}$ & 0.162 & 0.172 & 0.114 \\
\hline INOADM & 0.257 & 0.236 & 0.232 & 0.171 & 0.166 \\
\hline $\mathrm{N}$ & 54 & 54 & 54 & 54 & 54 \\
\hline
\end{tabular}

* Correlation is significant at the 0.05 level (2-tailed).

** Correlation is significant at the 0.01 level (2-tailed).

Source: Elaborated by the authors.

Given that organizational culture is primarily conceived in the literature as a group variable (Hofstede et al., 1993) and because of the large number of findings that assess the relationship between culture and innovation only at the organizational level, for comparative purposes, linear regression analysis was performed first.

After verifying the variability indices among organizations and intraorganizational cohesion, we performed the predictive analyses of the explanatory variables of aggregate organizational culture for the innovation response variable.

Figure 4.2.3 presents the result of the standard linear regression, considering the five organizational culture factors aggregated at the group level with respect to the innovation response variable, subdivided into five types. 


\section{(Figure 4.2.3)}

RESULT OF THE REGRESSION ANALYSIS INVOLVING ORGANIZATIONAL CULTURE FACTORS AND TYPES OF INNOVATIONS

\begin{tabular}{|c|c|c|c|c|c|c|c|c|}
\hline & \multicolumn{4}{|c|}{ Total innovation score } & \multicolumn{4}{|c|}{ Product innovation } \\
\hline & $\mathrm{R}$ & $\mathrm{R}^{2}$ & $\mathrm{R}^{2}$ adjusted & $p^{\star \star}$ & $\mathrm{R}$ & $\mathrm{R}^{2}$ & $\mathrm{R}^{2}$ adjusted & $p^{\star \star}$ \\
\hline & 0.39 & 0.152 & 0.139 & 0.00 & 0.289 & 0.084 & 0.069 & 0.00 \\
\hline & $\mathrm{b}$ & $\beta$ & $T$ & $P$ & $\mathrm{~b}$ & $\beta$ & $T$ & $p^{\star \star}$ \\
\hline Rituals and stories & 10.815 & 0.397 & 2.957 & $0.003^{\star \star \star}$ & 5.080 & 0.191 & 1.368 & 0.172 \\
\hline Innovation strategies & 1.710 & 0.399 & 3.906 & $0.000^{\star \star \star}$ & 14.913 & 0.357 & 3.357 & $0.001^{* * *}$ \\
\hline Symbols and heroes & -3.000 & -0.094 & -0.770 & 0.442 & -1.674 & -0.054 & -0.423 & 0.672 \\
\hline Autonomy & -13.135 & -0.373 & -0.370 & $0.000^{\star \star \star}$ & -10.609 & -0.308 & -2.943 & $0.003^{* * *}$ \\
\hline \multirow[t]{5}{*}{$\begin{array}{l}\text { Norms and } \\
\text { communication }\end{array}$} & -1.871 & -0.053 & -0.475 & 0.635 & 0.167 & 0.005 & 0.042 & 0.967 \\
\hline & \multicolumn{4}{|c|}{ Service innovation } & \multicolumn{4}{|c|}{ Technological innovation } \\
\hline & $\mathrm{R}$ & $\mathrm{R}^{2}$ & $\mathrm{R}^{2}$ adjusted & $p^{\star \star}$ & $\mathrm{R}$ & $\mathrm{R}^{2}$ & $\mathrm{R}^{2}$ adjusted & $p^{\star \star}$ \\
\hline & 0.467 & 0.218 & 0.206 & 0.00 & 0.41 & 0.168 & 0.154 & 0.00 \\
\hline & $\mathrm{b}$ & $\beta$ & $\mathrm{t}$ & $p^{\star \star}$ & $\mathrm{b}$ & $\beta$ & $T$ & $p^{\star \star}$ \\
\hline Rituals and stories & 1.358 & 0.534 & 4.141 & $0.000^{\star \star \star}$ & 0.949 & 0.414 & 3.112 & $0.002^{\star \star \star}$ \\
\hline Innovation strategies & -1.389 & -0.347 & -3.538 & $0.000^{\star \star \star}$ & 1.676 & 0.465 & 4.594 & $0.000^{\star * \star}$ \\
\hline Symbols and heroes & -1.137 & -0.381 & -3.252 & $0.001^{\star \star \star}$ & -0.558 & -0.208 & -1.717 & 0.087 \\
\hline Autonomy & 1.232 & 0.374 & 3.867 & $0.000^{\star \star \star}$ & -0.883 & -0.298 & -2.985 & $0.003^{\star \star \star}$ \\
\hline \multirow[t]{5}{*}{$\begin{array}{l}\text { Norms and } \\
\text { communication }\end{array}$} & 0.600 & 0.184 & 1.699 & 0.090 & -0.163 & -0.055 & -0.497 & 0.620 \\
\hline & \multicolumn{4}{|c|}{ Administrative innovation } & & & & \\
\hline & $\mathrm{R}$ & $\mathrm{R}^{2}$ & $\mathrm{R}^{2}$ adjusted & $p^{\star \star}$ & & & & \\
\hline & 0.384 & 0.147 & 0.134 & 0.00 & & & & \\
\hline & $\mathrm{b}$ & $\beta$ & $\mathrm{t}$ & $p^{\star \star}$ & & & & \\
\hline Rituals and stories & 3.496 & 0.690 & 5.119 & $0.000^{\star \star \star}$ & & & & \\
\hline Innovation strategies & 1.973 & 0.248 & 2.414 & $0.016^{\star \star \star}$ & & & & \\
\hline Symbols and heroes & 0.326 & 0.055 & 0.448 & 0.654 & & & & \\
\hline Autonomy & -2.874 & -0.438 & -4.335 & $0.000^{\star \star \star}$ & & & & \\
\hline $\begin{array}{l}\text { Norms and } \\
\text { communication }\end{array}$ & -2.518 & -0.387 & -3.424 & $0.001^{\star \star \star}$ & & & & \\
\hline
\end{tabular}

* Standardized regression coefficients.

** $p \leq 0,05$.

$\star \star \star$ Preditors

Source: Elaborated by the authors. 
According to Figure 4.2.3, the predictors of Total Innovation are Rituals and Stories, Strategies of Innovation, and Autonomy. In relation to Product Innovation, the predictors are Strategies of Innovation and Autonomy. The Service Innovations presented four predictors, those being Rituals and Stories, Strategies of Innovation, Symbols, and Heroes, and Autonomy. The Technological Innovations obtained Rituals and Stories, Strategies of Innovation, and Autonomy as predictors. The Administrative Innovations did not present Symbols and Heroes as predictors, but the other four cultural factors were predictors of the variable.

Autonomy presented a negative relation with Total Innovation, Product Innovation, Technological Innovation, and Administrative Innovation, demonstrating that this variable presents an inverse relation with four types of innovation evaluated - that is, the greater the autonomy in the organization, the less the presence of the specified innovations. Only Service Innovation presented a positive relationship with the Autonomy variable. However, Innovation Strategies and Symbols and Heroes were negatively related to Service Innovation - that is, the greater the development of innovation strategies and the greater the presence of characters and symbols that represent innovation in the organization, the smaller the number of innovations of service. Thus, some leadership and strategies may lead to inhibition of service innovation. In addition, Norms and Communication were related in a negative way with Administrative Innovations - that is, the greater the number of norms in the organization the less the number of administrative innovations.

\subsection{Results of multi-level analysis}

\subsubsection{Steps to generating the models}

The multilevel analysis of this study seeks to identify which variables predict innovation in the organizations evaluated. The modeling was done with the help of the MLwiN software version 2.35, and its construction considers the steps proposed by Hox (2002) and confirmed by Laros and Marciano (2008) and Ludtke et al. (2008).

First, the empty model was generated and analyzed, without the inclusion of any explanatory variable. The model fit index (deviance) was evaluated and compared to the following models. Lower deviance values suggest a better model fit. Through the empty model it is also possible to calculate an estimate of intraclass correlation based on the following equation (1): 


$$
\rho=\frac{\sigma_{u 0}^{2}}{\left(\sigma_{u 0}^{2}+\sigma_{e}^{2}\right)}
$$

The value $\sigma_{u 0}^{2}$ is the variance of errors $u_{0 j}$ at the organization level, and $\sigma_{e}^{2}$ is the variance of the errors $e_{i j}$ at the level of the organization members.

In the second step, the model with the explanatory variables, considering fixed effects at the individual level, is formed, and then the explanatory variables are added at the level of the organizations. Finally, it is evaluated whether the coefficients of the explanatory variables at the individual level present variance between the organizations and the interactions betweenlevels and between explanatory variables at the two levels that previously presented significant variance of coefficients are added to the model.

\subsubsection{Analysis of the multilevel models}

The following section is intended to describe the results of the multilevel analysis of the study. The first model, the Empty Model, is presented in Figure 4.3.2.1.

(Figure 4.3.2.1)

EMPTY MODEL

\begin{tabular}{llcl}
\multicolumn{1}{c}{ Explanatory variables } & \multicolumn{3}{c}{ Model 1 (without variables) } \\
\hline Fixed effect & Effect & Standard error & $t$ \\
\hline Intercept & 36.80 & 7.86 & - \\
\hline Random effect - level 2 - $\sigma_{\mathrm{u} 0}^{2}$ & & & 5.48 \\
\hline Variance - intercept & 3702.35 & 676.09 & 11.76 \\
\hline Random effect - level 1 - $\sigma_{\mathrm{e}}^{2}$ & & & \\
\hline$R_{\text {ij }}$ variance & 4.00 & 0.34 & \\
\hline Intraclass correlation & 0.999 & & \\
\hline Deviance & 1960.28 & & \\
\hline Number of estimated parameters & 3 &
\end{tabular}
$p<0.000$

Source: Elaborated by the authors.

Figure 4.3.2.1 shows a coefficient of 36.80 for the intercept, which can be interpreted as the average number of innovations performed in the last two years in the organizations studied. Moreover, the variance results show 
that there is a considerable difference in the innovation values of the various organizations, and the value of the ratio $t$ confirms that the variance of the intercept is significantly different from zero (critical value $=1.96$ ).

The Intraclass Correlation Coefficient (ICC $=$ of 0.99) shows that $99 \%$ of the variance of innovations can be attributed to the organizational level. Thus, this value is justifying the need for a multilevel approach.

Figure 4.3.2.2 presents Model 2, which consists of the level-one organizational culture variables in level 1: Rituals and Stories; Innovation Strategies; Symbols and Heroes; Autonomy; and Standards and Communication. The variance explained at the member level presents the following equation (2), proposed by Hox (2002):

$$
R_{1}^{2}=\left(\frac{\sigma_{\phi b}^{2}-\sigma_{\phi m}^{2}}{\sigma_{\phi b}^{2}}\right)
$$

where $\sigma_{\phi b}^{2}$ is the residual variance at the member level for $\mathrm{M} 1$, and $\sigma_{q m}^{2}$ is the residual variance at the member level for M2. Therefore:

$$
R_{1}^{2}=\left(\frac{4.00-3.88}{4.00}\right) \approx 0.03
$$

The variance proportion explained at the organizational level was calculated based on equation (3):

$$
R_{2}^{2}=\left(\frac{\sigma_{u|| b}^{2}-\sigma_{u|| m}^{2}}{\sigma_{u|| b}^{2}}\right)
$$

where $\sigma_{u \mid b}^{2}$ is the residual organizational-level variance for $\mathrm{M} 1$, and $\sigma_{u \mid m}^{2}$ is the residual organizational-level variance for M2. Therefore:

$$
R_{2}^{2}=\left(\frac{3702.35-3702.48}{3702.35}\right) \approx-0.004
$$

The model with explanatory variables at the organizational level (M3) has this variance for the individual level: 


$$
R_{2}^{2}=\left(\frac{4-3.88}{4}\right) \approx 0.03
$$

In model M3, for the organizational level:

$$
R_{2}^{2}=\left(\frac{3702.35-3594.26}{3702.35}\right) \approx 0.029
$$

The variance at the organizational level was practically unchanged, with a slight increase from 3702.35 to 3702.48 . At the member level, there was a drop in the variance from 4.0 to 3.88 . The intraclass correlation value remained the same (0.99) though.

Regarding the deviance, which represents the fit of the model, there was a reduction (8.9) from M1 to M2. This result demonstrates that model 2 fits the data better. The chi-square test $\left(\chi^{2}\right)$ yielded a value of 1.78 , reinforcing the conclusion of an improvement in the fit of the model. The introduction of the aggregate variables generated a more significant change in the variance between the organizations, from 3702.48 to 3594.26 , while the variance between the members did not present any change, and the intraclass correlation value was maintained at 0.99 in both models.

(Figure 4.3.2.2)

MODELS WITH LEVEL 1 (M2) AND LEVEL 2 (M3) EXPLANATORY VARIABLES

\begin{tabular}{lcccccc}
\multicolumn{1}{c}{ Explanatory variables } & \multicolumn{3}{c}{ Model 2 (M2) } & \multicolumn{3}{c}{ Model 3 (M3) } \\
\hline \multicolumn{1}{c}{ Fixed effect } & Effect & $\begin{array}{c}\text { Standard } \\
\text { error }\end{array}$ & T & Effect & $\begin{array}{c}\text { Standard } \\
\text { error }\end{array}$ & $t$ \\
\hline Intercept & 36.59 & 7.9 & - & 60.4 & 68.15 & - \\
\hline Rituals and stories & 0.30 & 0.13 & $* 2.31$ & 0.30 & 0.13 & $* 2.31$ \\
\hline Innovation strategies & 0.24 & 0.15 & 1.60 & 0.23 & 0.15 & 1.53 \\
\hline Symbols and heroes & -0.33 & 0.15 & $*-2.20$ & -0.33 & 0.15 & $*-2.20$ \\
\hline Autonomy & -0.04 & 0.15 & -0.27 & -0.04 & 0.15 & -0.27 \\
\hline Standards and communication & -0.16 & 0.13 & -1.23 & -0.16 & 0.13 & -1.23 \\
\hline Rituals and stories_aggregated & & & & 3.28 & 14.77 & -0.22 \\
\hline Innovation strategies_aggregated & & & & 14.49 & 20.23 & 0.72 \\
\hline
\end{tabular}


(Figure 4.3.2.2 (conclusion))

MODELS WITH LEVEL 1 (M2) AND LEVEL 2 (M3)

EXPLANATORY VARIABLES

\begin{tabular}{|c|c|c|c|c|c|c|}
\hline \multirow{2}{*}{$\begin{array}{c}\text { Explanatory variables } \\
\text { Fixed effect }\end{array}$} & \multicolumn{3}{|c|}{ Model 2 (M2) } & \multicolumn{3}{|c|}{ Model 3 (M3) } \\
\hline & Effect & $\begin{array}{c}\text { Standard } \\
\text { error }\end{array}$ & $\mathrm{T}$ & Effect & $\begin{array}{c}\text { Standard } \\
\text { error }\end{array}$ & $t$ \\
\hline Symbols and heroes_aggregated & & & & 6.16 & 17.08 & 0.36 \\
\hline Aautonomy_aggregated & & & & -18.98 & 15.96 & -1.19 \\
\hline Standards and communication_aggregated & & & & -11.34 & 15.88 & -0.71 \\
\hline \multicolumn{7}{|l|}{ Random effect - level $2-\sigma_{u 0}^{2}$} \\
\hline Variance - intercept & 3702.48 & 676.12 & 5.48 & 3594.26 & 656.38 & 5.47 \\
\hline \multicolumn{7}{|l|}{ Random effect - level $1-\sigma_{e}^{2}$} \\
\hline$R_{i j}$ variance & 3.88 & 0.32 & 12.125 & 3.88 & 0.32 & 12.125 \\
\hline Conditional intraclass correlation & 0.99 & & & 0.99 & & \\
\hline Deviance & 1951.38 & & & 1949.6 & & \\
\hline Number of estimated parameters & 8 & & & 13 & & \\
\hline Difference of deviance M1 - deviance M2 & 8.9 & & & & & \\
\hline Difference of parameters M2-M1 & 5 & & & & & \\
\hline Test $\chi^{2}$ & 1.78 & & & & & \\
\hline Difference of deviance M2 - deviance M3 & & & & 1.78 & & \\
\hline Difference of parameters M3-M2 & & & & 5 & & \\
\hline$\chi^{2}$ Test & & & & 0.356 & & \\
\hline Level 1 variance & $99.90 \%$ & & & $3.00 \%$ & & \\
\hline Level 2 variance & $-0.004 \%$ & & & $2.92 \%$ & & \\
\hline
\end{tabular}

Source: Elaborated by the authors.

Model 2 shows that Rituals and Stories and Symbols and Heroes influence the production of innovations in organizations. Rituals and Stories influence innovation positively and the second variable (Symbols and Heroes) negatively, both at the individual level.

Thus, with regard to Rituals and Stories, the results support hypothesis H1a. The perception of the organization's members about events to encourage, teach, and celebrate innovations, stories told about successful innovations, and the delivery of awards for important innovations are elements associated with the production of innovations in organizations. Hypothesis $\mathrm{H} 3 \mathrm{a}$ is not supported by these study results, insofar as the perception of Symbols and Heroes at the individual level is negatively related to innovation. 
Regarding the Innovation score, organizational culture factors are responsible for explaining $15.2 \%$ of the variability of innovations. Analyzing standardized regression coefficients, it is evident that Innovation Strategies and Rituals and Stories generate a greater impact on the response variable.

Organizational culture factors explain only $8.4 \%$ of the variability of Product Innovation, including Innovation Strategies as the most important predictor in the regression equation. Regarding Service Innovation, 21.8\% of its variability is explained by cultural factors, the highest index of explanation among the studied variables. Considering this relationship, the most influential factors were Rituals and Stories and Symbols and Heroes. Organizational culture factors explain $16.8 \%$ of the variability in relation to Technological Innovation, with a greater importance being attributed to the variables Innovation Strategies and Rituals and Stories. As for Administrative Innovation, the organization cultural factors explain $14.7 \%$ of the variability, in which Rituals and Stories and Autonomy generate greater influence on the response variable. Both results of linear regression and multilevel analysis are consonant with respect to the influence of Rituals and Stories on the overall production of innovations within organizations, considering all types of innovation.

\section{DISCUSSION AND CONCLUSIONS}

The Rituals and Stories regarding innovations showed positive relations with four types of innovation, corroborating hypothesis $\mathrm{H} 1 \mathrm{~b}$. This reinforces the importance of the theme according to the literature in the area, emphasizing the need for stories in the organizational culture as an interpretation of the reality in the same way that rites reinforce group mythology (Pettigrew, 1979; Jarnagin \& Slocum Jr., 2007; Bockstedt, Druehl, \& Mishra, 2015).

The Innovation Strategies proved to be significant in predicting all types of Innovation, but with a negative relation in service innovations, thus partially confirming hypothesis $\mathrm{H} 2 \mathrm{~b}$. The literature emphasizes that highimpact strategies require a cultural change to generate success. Otherwise, changes are superficial and short-lived (Cameron \& Quinn, 2011). Therefore, the strategy is studied as a determinant of innovation (Martins \& Terblanche, 2003), reinforced by the evidence of this study.

The Symbols and Heroes are only present in the Service Innovations, but in a negative way. Hypothesis H3b is therefore refuted in this study, insofar as positive relations between Symbols and Heroes and Innovation are not evidenced. The literature reinforces the influence of founders and 
leaders in the formation of organizational culture because they are models of behavior. The role of the symbols lies in the fact that they are considered cultural diffusers (Schein, 1990; Pettigrew, 1979; Cameron \& Quinn, 2011; Yin et al., 2014). However, there is also evidence for the possibly inhibiting effect of organizational culture on innovation (Valencia, Valle, \& Jimenez, 2010; Martins \& Terblanche, 2003; Naranjo-Valencia et al., 2012; NaranjoValencia et al., 2011).

Autonomy presented a significant relationship with all types of innovation, but the positive association was only found with Service Innovation. This association partially corroborates hypothesis H4b. This negative relationship with some types of innovation can be explained by the presence or not of feedback in supervisor and employee interactions (Battistelli, Montani, \& Odoardi, 2013). In some cases, without feedback that provides direction to employee behavior, autonomy cannot foster innovative actions. In some cases, autonomy without management direction may inhibit innovation (Battistelli et al., 2013).

Standards and Communication predict only Administrative Innovation, in a negative relation, which refutes hypothesis H5b. Administrative Innovations are those that deal directly with the standards and communication of the organization, which is coherent with the presence of this specific relationship. In addition, the literature reinforces the standards and communication as elements intrinsic to the organizational culture. Depending on how they influence the behavior of individuals and the group, these elements may support or inhibit innovation (Nacinovic et al., 2010; Martins \& Terblanche, 2003; Pratoom \& Savatsomboon, 2012; Sharifirad \& Ataei, 2012; Hogan \& Coote, 2014; Schein, 1990).

The stories are important components in the formation of organizational culture (Pettigrew, 1979; Schein, 1990), and rituals reinforce group mythology (Jarnagin \& Slocum Jr., 2007), concretizing the characteristics the members of the organization have built and shared.

Autonomy was perceived in this study as an inhibitor of innovation. If the organization gives the member greater freedom to create and implement new elements, it can generate the inverse effect on the employee, reducing the number of innovations produced. Values, standards, and beliefs that play a role in innovation can either support or inhibit creativity and innovation, depending on how they influence individual and group behavior (Martins \& Treblanche, 2003). According to this study's results, the companies cannot foster autonomy without an explicit purpose that directs creative and innovative behavior (Montani et al., 2014). 
The Innovation Strategies were positively related to all types of innovation in the regression analyses, and they demonstrated values close to the criterion, at the individual level, strengthening the tendency towards an association between the variable and innovation. This indicates the importance of organizational direction in relation to innovation because autonomy without direction may be ineffective and capable of generating inverse results.

Supporting the literature of the area, this study demonstrated the existence of predictive effects between cultural characteristics and innovation and the existence of positive and negative relations between variables. This reinforces the importance of the theme and the need for more empirical research in the area. These findings entail important implications for managers and policy-makers. First, culture matters. Companies may not be able to increase their rates of innovation simply by increasing the amount of money spent on infrastructure. They may also need to change the values of their members to those that encourage innovative activity. This concept, in turn, suggests that organizational rates of innovation are driven by more fundamental forces than economic and structural conditions and that organizational change may be necessary to make less innovative companies more innovative.

Second, the values associated with high organizational rates of innovation are those that, as many scholars have long argued, is important at the firm level. Symbols and Heroes appear to be necessary, probably because innovation values require practical examples, modeling individuals' behavior. Innovation Strategies seem to be important, perhaps because they require cultural change and can foster association with autonomy, independence, and freedom. Rituals and Stories are another important aspects, perhaps reflecting the role that tolerance of change in the social order and distribution of power play in the innovation process.

As practical implications, the work permits an initial understanding of the cultural elements that can support or inhibit innovation. This information can be used as an organizational diagnostic tool for innovation management.

The small sample, formed by small companies, limited the present study, preventing generalizations and more robust results. Therefore, research with a larger number of larger organizations is suggested. Small organizations possess specific characteristics that make some relationships more intense or reduced in this context (Néto \& Teixeira, 2014). With the intention of generating more profound multilevel analyses, another suggestion is the evaluation of innovation at the individual level, as innovative behavior. 
Moreover, while we identified that the impact of different levels of cultural dimensions on innovation is various, including both positive and negative or even mixed effects, given the scope of our research, there are many other complex issues, warranting scholars in the future for further investigations. Future research should explore the indirect effects of cultural dimensions on innovations, exploring them as mediational and moderator variables. Therefore, future research needs to verify and reveal results about the effects of these cultural dimensions on innovation considering longitudinal empirical research. Such kinds of a longitudinal study of the influence of culture on innovation along the lines of historical development may be highly promising in terms of pointing out the future research direction by posing a number of challenging questions. Future research should also explore the impact of the interrelationship between organizational culture and national culture on innovation - for example:

- what type of corporate culture favors the innovation of multinational corporations in the host country that is characterized by uncertain avoidance?

- how do corporations make the workers who have different cultures adapt to and accept the corporate culture?

Finally, a meta-analysis may provide a statistical integration of the accumulated research on the relationship between specific cultural dimension and innovation.

\section{INOVAÇÃO NAS EMPRESAS E ORIENTAÇÃO CULTURAL À INOVAÇÃO: UM ESTUDO MULTINÍVEL}

\section{RESUMO}

Objetivo: Testar a influência da orientação cultural para a inovação no número de inovações mensuradas em empresas brasileiras.

Originalidade/valor: O estudo utiliza uma abordagem que ainda não foi explorada na área, a análise multinível.

Design/metodologia/abordagem: Cinco fatores de orientação cultural para a inovação foram considerados: rituais e histórias; estratégias de inovação; símbolos e heróis; autonomia; e normas e comunicação. A inovação 
foi subdividida em quatro tipos: produto, serviço, tecnológico e administrativo. $\mathrm{O}$ estudo consistiu em uma amostra de 345 indivíduos em 60 organizações. A relação entre as variáveis foi analisada usando regressão linear e modelagem multinível.

Resultados: Os resultados da análise de regressão mostraram relações positivas e negativas de todos os fatores culturais com algum tipo de inovação. A análise multinível indicou uma relação entre as duas variáveis apenas nos fatores rituais e histórias e símbolos e heróis, ambos no nível individual. O estudo indica a existência de características da cultura organizacional que favorecem e inibem a inovação. Além disso, destacam-se a complexidade do assunto e a consequente necessidade de novos estudos.

\section{PALAVRAS-CHAVE}

Cultura organizacional. Inovação. Orientação cultural para inovação. Tipos de inovação. Análise multinível.

\section{REFERENCES}

Ali, M., \& Park, K. (2016). The mediating role of an innovative culture in the relationship between absorptive capacity and technical and non-technical innovation. Journal of Business Research, 69(5), 1669-1675.

Anderson, N., Potocnik, K., \& Zhou, J. (2014). Innovation and creativity in organizations: A state-of-the-science review and prospective commentary. Journal of Management, 40(5), 1297-1333.

Baković, T., Lazibat, T., \& Sutić, I. (2013). Radical innovation culture in Croatian manufacturing industry. Journal of Enterprising Communities: People and Places in the Global Economy, 7(1), 74-80.

Battistelli, A., Montani, F., \& Odoardi, C. (2013). The impact of feedback from job and task autonomy in the relationship between dispositional resistance to change and innovative work behavior. European Journal of Work and Organizational Psychology, 22:1, 26-41. doi:10.1080/1359432X. 2011.616653 
Bockstedt, J., Druehl, C., \& Mishra, A. (2015). Problem-solving effort and success in innovation contests: The role of national wealth and national culture. Journal of Operations Management, 36, 187-200.

Brettel, M., \& Cleven, N. J. (2011). Innovation culture, collaboration with external partners and NPD performance. Creativity and Innovation Management, 20(4), 253-272.

Bruno-Faria, M. F., \& Fonseca, M. V. A. (2014). Cultura de inovação: Conceitos e modelos teóricos. Revista de Administração Contemporânea, 18(4), 372-396.

Büschgens, T., Bausch, A., \& Balkin, D. B. (2013). Organizational culture and innovation: A meta-analytic review. Journal of Product Innovation Management, 30, 763-781. doi:10.1111/jpim.12021

Cameron, K. S., \& Quinn, R. E. (2011). Diagnosing and changing organizational culture: Based on the competing values framework (3rd ed.). San Francisco, CA: John Wiley \& Sons.

Chang, S. C., \& Lee, M. S. (2007). The effects of organizational culture and knowledge management mechanisms on organizational innovation: An empirical study in Taiwan. The Business Review, 7(1), 295-301.

Chen, G., Farh, J.-L., Campbell-Bush, E. M., Wu, Z., \& Wu, X. (2013). Teams as innovative systems: Multilevel motivational antecedents of innovation in R\&D teams. Journal of Applied Psychology, 98, 1018-1027.

Damanpour, F., \& Gopalakrishnan, S. (2001). The dynamics of the adoption of product and process innovations in organizations. Journal of Management Studies, 38, 45-65. doi:10.1111/1467-6486.00227

Damanpour, F., Walker, R. M., \& Avellaneda, C. N. (2009). Combinative effects of innovation types and organizational performance: A longitudinal study of service organizations. Journal of Management Studies, 46, 650-675. doi:10.1111/j.1467-6486.2008.00814.x

Demirci, A. E. (2013). Strategic representation of an abstract reality: Spiraling relations between organizational culture and innovativeness. Journal of Management and Strategy, 4(3), 39-55.

Dobni, C. B. (2008). Measuring innovation culture in organizations: The development of a generalized innovation culture construct using exploratory factor analysis. European Journal of Innovation Management, 11 (4), 539-559.

Fagerberg, J., Martin, B. R., \& Anderson, E. S. (2013). Innovation Studies: Evolution and Future Challenges. Oxford University Press, 2013. 
Fernandes, C. I., Ferreira, J. M. M., \& Raposo, M. L. (2013). Drivers to firm innovation and their effects on performance: An international comparison. International Entrepreneurship and Management Journal, 9(4), 557-580.

Francischeto, L. L. (2016). Inovação e orientação cultural: Evidências de validade de construto e preditiva (Masters Dissertation). Universidade de Brasília, Brasília, DF: Brazil, $110 \mathrm{f}$.

Gobara, C., Rossoni, L., Kato, E., Dossa, A. A., \& Hocayen-da-Silva, A. J. (2010). A influência das dimensões da cultura organizacional na inovação em serviços: Uma análise do setor hoteleiro. Base - Revista de Administração e Contabilidade da Unisinos, 7(4), 252-265.

Gomes, G., Machado, D., \& Alegre, J. (2015). Determinants of innovation culture: A study of textile industry in Santa Catarina. Brazilian Business Review, 12(4), 99-122.

Hartnell, C. A., Ou, A. Y., \& Kinicki, A. (2011). Organizational culture and organizational effectiveness: A meta-analytic investigation of the competing values framework's theoretical suppositions. Journal of applied psychology, 96(4), 677-694.

Hofstede, G. (1998). Attitudes, values and organizational culture: Disentangling the concepts. Organization Studies, 19(3), 477-493.

Hofstede, G., Bond, M. H., \& Luk, C. (1993). Individual perceptions of organizational cultures: A methodological treatise on levels of analysis. Organization Studies, 14(4), 483-503.

Hogan, S. J., \& Coote, L. V. (2014). Organizational culture, innovation, and performance: A test of Schein's Model. Journal of Business Research, 67(8), 1609-1621.

Hox, J. J. (2002). Multilevel Analysis: Techniques and Applications. Mahwah, NJ: Lawrence Erlbaum Associates.

Hyland, P., \& Beckett, R. (2005). Engendering an innovative culture and maintaining operational balance. Journal of Small Business and Enterprise Development, 12(3), 336-352.

Isaksen, S. G., \& Ekvall, G. (2010). Managing for innovation: The two faces of tension in creative climates. Creativity and innovation management, 19(2), 73-88.

Jassawalla, A. R., \& Sashittal, H. C. (2002). Cultures that support productinnovation processes. Academy of Management Perspectives, 16 (3), 42-54.

James, L. R. (1982). Aggregation bias in estimates of perceptual agreement. Journal of Applied Psychology, 67(2), 219-229. doi:10.1037/0021-9010. 67.2.219 
James, L. R., Demaree, R. G., \& Wolf, G. (1984). Estimating within-group interrater reliability with and without response bias. Journal of applied psychology, 69(1), 85-98.

James, L. R., Demaree, R. G., \& Wolf, G. (1993). rwg: An assessment of within-group interrater agreement. Journal of applied psychology, 78(2), 306-309.

Jamrog, J., Vickers, M., \& Bear, D. (2006). Building and sustaining a culture that supports innovation. People and Strategy, 29(3), 9-19.

Jarnagin, C., \& Slocum Jr., J. W. (2007). Creating corporate cultures through mythopoeic leadership. Organizational Dynamics, 36(3), 288-302.

Jaskyte, K., \& Dressler, W. W. (2005). Organizational culture and innovation in nonprofit human service organizations. Administration in Social Work, 29, 23-41.

Kalyar, M. N., \& Rafi, N. (2013). Organizational learning culture: An ingenious device for promoting firm's innovativeness. The Service Industries Journal, 33(12), 1135-1147.

Khazanchi, S., Lewis, M. W., \& Boyer, K. K. (2007). Innovation-supportive culture: The impact of organizational values on process innovation. Journal of operations management, 25(4), 871-884.

Kenny, B., \& Reedy, E. (2006). The impact of organisational culture factors on innovation levels in SMEs: An empirical investigation. Irish Journal of Management, 27(2), 119-142.

Laros, J. A., \& Marciano, J. L. P. (2008). Análise multinível aplicada a dados do NELS:88. Estudos em Avaliação Educacional, 19(40), 263-278.

Lau, C. M., \& Ngo, H. Y. (2004). The HR system, organizational culture, and product innovation. International business review, 13(6), 685-703.

Lin, T-Y., Chuang, L.-M., Chang, M.-Y., \& Yeh, C.-M. (2012). A study of the relationship between team innovation and organizational innovation in the high-tech industry: Confirmation of the organizational culture moderation effect. Advances in Management \& Applied Economics, 2, 2, 19-52.

Linke, A., \& Zerfass, A. (2011). Internal communication and innovation culture: Developing a change framework. Journal of Communication Management, 15(4), 332-348.

Lüdtke, O., Marsh, H. W., Robitzsch, A., Trautwein, U., Asparouhov, T., \& Muthén, B. (2008). The multilevel latent covariate model: A new, more reliable approach to group-level effects in contextual studies. Psychological methods, 13(3), 203-229. 
Lyons, R. K., Chatman, J. A., \& Joyce, C. K. (2007). Innovation in services: Corporate culture and investment banking. California management review, 50(1), 174-191.

Machado, D. D. P. N., \& de Vasconcellos, M. A. (2007). Organizações inovadoras: Existe uma cultura específica que faz parte deste ambiente?. REGE (Revista de Gestão), 14(4), 15-31.

Machado, D. D. P. N., Gomes, G., Trentin, G. N. S., \& Silva, A. (2013). Cultura de inovação: Elementos da cultura que facilitam a criação de um ambiente inovador. RAI (Revista de Administração e Inovação), 10(4), 164-182.

Martín-de Castro, G., Delgado-Verde, M., Navas-López, J., and Cruz-González, J. (2013). The moderating role of innovation culture in the relationship between knowledge assets and product innovation. Technological Forecasting and Social Change, 80(2), 351-363.

Martins, E., \& Martins, N. (2002). An organisational culture model to promote creativity and innovation. SA Journal of Industrial Psychology, 28(4), $58-65$.

Martins, E., \& Terblanche, F. (2003). Building organisational culture that stimulates creativity and innovation. European Journal of Innovation Management, 6(1), 64-74.

McLean, L. D. (2005). Organizational culture's influence on creativity and innovation: A review of the literature and implications for human resource development. Advances In Developing Human Resources, 7(2), 226-246.

Meyer, J. (2014). Strengthening innovation capacity through different types of innovation cultures. Technology Innovation Management Review, 4, 6-16.

Miron, E., Erez, M., \& Naveh, E. (2004). Do personal characteristics and cultural values that promote innovation, quality, and efficiency compete or complement each other? Journal of Organizational Behavior, 25(2), 175-199.

Montani, F., Odoardi, C., \& Battistelli, A. (2014). Individual and contextual determinants of innovative work behaviour: Proactive goal generation matters. Journal of Occupational and Organizational Psychology, 87(4), 645-670. doi:10.1111/joop.12066

Montalvo, C. (2006). What triggers change and innovation?. Technovation, 26(3), 312-323.

Mumford, M. D. (2000). Managing creative people: Strategies and tactics for innovation. Human Resource Management Review, 10(3), 313-351.

Nacinovic, I., Galetic, L., \& Cavlek, N. (2010). Corporate culture and innovation: Implications for reward systems. International Journal of Social, Behavioral, Educational, Economic, Business and Industrial Engineering, 3(5), 376-381. 
Naranjo-Valencia, J. C., Sanz-Valle, R., \& Jiménez-Jiménez, D. (2010). Organizational culture as determinant of product innovation. European Journal of Innovation Management, 13(4), 466-480.

Naranjo-Valencia, J., Jiménez-Jiménez, D., \& Sanz-Valle, R. (2011). Innovation or imitation? The role of organizational culture. Management Decision, 49(1), 55-72.

Naranjo-Valencia, J., Jimènez-Jimènez, D., \& Sanz-Valle, R. (2012). Es la cultura organizativa un determinante de la innovación en la empresa?. Cuadernos de Economía y Dirección de la Empresa, 15, 63-72.

Naranjo-Valencia, J. C., Jiménez-Jiménez, D., \& Sanz-Valle, R. (2016). Studying the links between organizational culture, innovation, and performance in Spanish companies. Revista Latinoamericana de Psicología, 48(1), 30-41.

Néto, A. T. S., \& Teixeira, R. M. (2014). Inovação de micro e pequenas empresas: Mensuração do grau de inovação de empresas participantes do Projeto Agentes Locais de Inovação. Brazilian Business Review, 11 (4), 1-29.

O'Reilly, C., Chatman, J., \& Caldwell, D. (1991). People and organizational culture: A profile comparison approach to assessing person-organization fit. Academy of Management Journal, 34, 3, 487-516.

Pasquali, L. (2012). Análise Fatorial para pesquisadores. Brasília, DF: Labpam.

Pettigrew, A. (1979). On studying organizational cultures. Administrative Science Quarterly, 4, pp. 570-581.

Prajogo, D. I., \& McDermott, C. M. (2011). The relationship between multidimensional organizational culture and performance. International Journal of Operations \& Production Management, 31 (7), 712-735.

Pratoom, K., \& Savatsomboon, G. (2012). Explaining factors affecting individual innovation: The case of producer group members in Thailand. Asia Pacific Journal of Management, 29(4), 1063-1087.

Sanz-Valle, R., Naranjo-Valencia, J., Jiménez-Jiménez, D., \& Perez-Caballero, L. (2011). Linking organizational learning with technical innovation and organizational culture. Journal of Knowledge Management, 15(6), 997-1015.

Schein, E. H. (1990). Organizational culture. American Psychologist, 45, 109-119. Schein, E. H. (2010). Organizational culture and leadership. San Francisco, CA: Jossey-Bass.

Schneider, B., Ehrhart, M. G., \& Macey, W. H. (2013). Organizational climate and culture. Annual Review of Psychology, 64, 361-88. 
Sharifirad, M. S., \& Ataei, V. (2012). Organizational culture and innovation culture: Exploring the relationships between constructs. Leadership \& Organization Development Journal, 33(5), 494-517.

Škerlavaj, M., Song, J. H., \& Lee, Y. (2010). Organizational learning culture, innovative culture and innovations in South Korean firms. Expert systems with applications, 37(9), 6390-6403.

Snijders, T. A. B., \& Bosker, R. (2002). Multilevel analysis: An introduction to basic and advanced multilevel modeling (2nd ed.). London: SAGE.

Von Stamm, B. (2009). Leadership for innovation: What you can do to create a culture conducive to innovation. Strategic Direction, 25(6), 13-15.

Steiber, A., \& Alänge, S. (2013). A corporate system for continuous innovation: The case of Google Inc. European Journal of Innovation Management, 16(2), 243-264.

Stock, R., Six, B., and Zacharias, N. (2013). Linking multiple layers of innovation-oriented corporate culture, product program innovativeness, and business performance: A contingency approach. Journal of the Academy of Marketing Science, 41(3), 283-299.

Tellis, G. J., Prabhu, J. C., \& Chandy, R. K. (2009). Radical innovation across nations: The preeminence of corporate culture. Journal of marketing, 73(1), $3-23$.

Tian, M., Deng, P., Zhang, Y., Salmador, M.P. (2018). How does culture influence innovation? A systematic literature review. Management Decision, 56(5), 1088-1107. doi:10.1108/MD-05-2017-0462

Tidd, J., Bessant, J., \& Pavitt, K. (2005). Managing innovation integrating technological, market and organizational change. Sussex: John Wiley and Sons Ltd.

Wang, H., Begley, T., Hui, C., and Lee, C. (2012). Are the effects of conscientiousness on contextual and innovative performance context specific? Organizational culture as a moderator. International Journal of Human Resource Management, 23(1), 174-189.

Yin, S., Lu, F., Yang, Y., \& Jing, R. (2014). Organizational culture evolution: An imprinting perspective. Journal of Organizational Change Management, 27(6), 973-994.

Zhu, C., \& Engels, N. (2014). Organizational culture and instructional innovations in higher education: Perceptions and reactions of teachers and students. Educational Management Administration \& Leadership, 42(1), $136-158$. 


\section{AUTHOR NOTES}

Leela L. Francischeto, Departamento de Psicologia Social, do Trabalho e das Organizações, Universidade de Brasília (UnB); Elaine R. Neiva, Programa de Pós-Graduação em Psicologia, Universidade de Brasilia (UnB).

Leela L. Francischeto is now Doctorate Student at Departamento de Psicologia Social, do Trabalho e das Organizações from the Universidade de Brasília; Elaine R. Neiva is now Associate Professor IV at Departamento de Administração from the Universidade de Brasília (UnB).

Correspondence concerning this article should be addressed to Leela L. Francischeto, SQN 206 bloco G, Asa Norte, Brasília, DF, Brazil, CEP 70844-070.

E-mail: leela.francischeto@gmail.com

\section{EDITORIAL BOARD}

Editors-in-chief Janette Brunstein

Silvio Popadiuk

Associated Editor

Thais Vick

Technical Support

Vitória Batista Santos Silva

\section{EDITORIAL PRODUCTION}

Publishing Coordination

Irina Migliari

Layout Designer

Emap

Copyeditor

Irina Migliari (English)

Graphic Designer

Libro
Language Editor

Daniel de Almeida Leão (English)

Irina Migliari (Portuguese) 